\title{
Removal of Chromium(VI) from Aqueous Solution using a Strong base Anion Exchange Resin : Kinetic and Equilibrium Studies
}

HARISH NAGESH REVANKAR ( $\sim$ hnrevankar@git.edu )

KLS, GOGTE INSTITUTE OF TECHNOLOGY, BELAGAVI https://orcid.org/0000-0002-8273-6251

PRASANNA S KOUJALAGI

KLS GOGTE INSTITUTE OF TECHNOLOGY, BELAGAVI

VIJAYENDRA R GURJAR

KLS, GOGTE INSTITUTE OF TECHNOLOGY, BELAGAVI

RAVIRAJ M KULKARNI

KLS, GOGTE INSTITUTE OF TECHNOLOGY, BELAGAVI

\section{Research Article}

Keywords: Adsorption, Anion exchange resin, Chromium (VI), Kinetics

Posted Date: May 21st, 2021

DOl: https://doi.org/10.21203/rs.3.rs-413638/v1

License: (a) (i) This work is licensed under a Creative Commons Attribution 4.0 International License. Read Full License 


\title{
Removal of Chromium(VI) from aqueous solution using a strong base anion exchange resin: Kinetic and Equilibrium studies
}

\author{
Harish N. Revankar*, Prasanna S. Koujalagi, Vijayendra R. Gurjar and Raviraj M. Kulkarni \\ Department of Chemistry, KLS, Gogte Institute of Technology, Belagavi 590008, affiliated to Visvesvaraya \\ Technological University, Belagavi, Karnataka, India. \\ Email: hnrevankar@git.edu \\ ORCID ID: 0000-0002-8273-6251
}

\begin{abstract}
The removal of chromium (VI) from aqueous solution using the strong base anion exchange resin Tulsion A-62 (MP) is reported in this study under a variety of experimental conditions, including initial chromium (VI) concentration, contact time, and medium $\mathrm{pH}$. The ion-exchange process for the resin Tulsion A-62 (MP) was relatively simple and after 300 minutes of phase contact, the equilibrium was achieved. The sorption process, which is $\mathrm{pH}$ based, extracted the most chromium (VI) when the $\mathrm{pH}$ was between 4.0 and 5.0. Both Langmuir and Freundlich adsorption isotherms were used to fit the equilibrium results for $\mathrm{Cr}(\mathrm{VI})$ adsorption , however Langmuir isotherm model was found to be more acceptable for the $\mathrm{Cr}(\mathrm{VI})$ adsorption and maximum adsorption capacity of $\mathrm{Cr}(\mathrm{VI})$ was found to be $201.6 \mathrm{mg} / \mathrm{g}$. Scanning Electron Microscopy with EDX and Fourier transformed infrared spectroscopy were also used to characterize Tulsion A-62 (MP) before and after chromium adsorption. The adsorption mechanism followed reversible first-order kinetics. The findings showed that such anion-exchange resins can be used to effectively extract chromium (VI) ions from water and wastewater.
\end{abstract}

Keywords Adsorption, Anion exchange resin, Chromium (VI), Kinetics.

\section{Introduction}

In recent years, there has been a surge in interest in developing environmentally friendly technologies to treat toxic compounds in wastewater, especially municipal and industrial wastewaters. The organic and toxic compounds present in waste waters, such as pesticides, pharmaceuticals substances, heavy metals etc. Heavy metals such as chromium, cadmium, lead, arsenic, nickel, copper, and others can be present in waste streams originating from mining activities, metal plating, paints and pigments, electricity storage, electrical equipment production facilities, tanneries, and photography, with amounts exceeding the Environmental Protection Agency's (EPA) standard limits. Heavy metal contamination in the atmosphere has harmed not only marine flora and fauna [1-2], but also wildlife and humans, posing several serious health threats. Steel, metallurgical, chemical, refractory, plating, leather tanning, dye making, film and photography, metal finishing, mining, cement, rubber, textile, and other industries can produce chromiumcontaining wastewaters [3-4]. In the waste stream, chromium occurs in two forms: non-toxic $\mathrm{Cr}$ (III) and highly-toxic $\mathrm{Cr}(\mathrm{VI}) . \mathrm{Cr}(\mathrm{III})$ is an important dietary supplement for human and animal metabolism, while $\mathrm{Cr}(\mathrm{VI})$ is a carcinogenic, teratogenic, and mutagenic substance that affects DNA transcription [5]. The maximum permissible limit for chromium in drinking water, according to WHO guideline, is $0.05 \mathrm{mg} \mathrm{L}^{-1}[6]$. Asthma, dermatitis, nasal inflammation, lung and gastrointestinal cancer are among the diseases caused by human exposure to $\mathrm{Cr}(\mathrm{VI})$ by food or water [7]. As a result, sophisticated methods for treating chromium-contaminated water have become essential. Several strategies for removing $\mathrm{Cr}(\mathrm{VI})$ from waste water have been suggested in the literature. Adsorption, precipitation, coagulation, phytoextraction, ultrafiltration, membrane separations, reverse osmosis, solvent extraction, electrodialysis, and evaporation are some of the techniques used. In terms of simplicity, convenience, high capacity and high recovery rate, ion exchange is the most beneficial approach among all. When it comes to wastewater treatment, ion exchange resins have a special role to play. Ion exchange is a sorption mechanism in which ions in solution are transferred to a solid matrix containing ions with equal polarity [8]. This method differs from adsorption in that it necessitates the exchange of materials in order to maintain electro-neutrality. The adsorbent or the contaminant undergo no chemical changes, but regeneration is needed to replace the ions that have been adsorbed. Ion exchangers are much like conventional adsorbents when it comes to remove toxic contaminants from wastewater. Small porous polymeric beads with a polystyrene matrix that carry fixed ions are referred to as ion-exchange resins [9]. To neutralize the fixed ions, free-moving counter-ions are incorporated into the resin. The functional groups that attract the solute are 
found in fixed ions, which are then substituted for mobile counter-ions. The main objective of the present study is to evaluate the efficiency of the anion exchange resin Tulsion A-62(MP) for removing $\mathrm{Cr}(\mathrm{VI})$ from aqueous solution.

\section{Methodology}

Thermax Limited, Pune, India, given the ion exchanger Tulsion A-62(MP) in chloride form. The resin was macroporous and crosslinked with quaternary ammonium type I functional polystyrene. The resin beads had a diameter of 0.3-1.2 $\mathrm{mm}$ and a moisture content of $41.4 \%$, with a total ion exchange capacity of $0.72 \mathrm{~m}$. eq. $/ 250 \mathrm{~g}$. Prior to the tests, the resin was pre-treated with $\mathrm{NaOH}$ and $\mathrm{HCl}$ solutions, then cleaned with distilled water and dried in air. The experiments were done in batches in the temperature-controlled shaking unit by stirring $30 \mathrm{ml}$ of aqueous solution containing Chromium (VI) with a particular amount of resin for $6 \mathrm{~h}$ at $303 \mathrm{~K}$. After that, the solution was spectrophotometrically analysed for $\mathrm{Cr}(\mathrm{VI})$ using a standard diphenyl carbazide (DPC) method at a wavelength of $540 \mathrm{~nm}$ [10]. Chromium (VI) recovery factors were calculated [11] using the equation (1).

$$
\% R=\frac{C_{a}}{C_{o}} \times 100
$$

where $C_{a}$ and $C_{o}$ are the Chromium (VI) concentrations on Tulsion A-62 and in the initial solution (in mg/L) respectively.

Coefficient distribution constant is given by the equation (2).

$$
K_{d}=\frac{q_{e}}{C_{e}}
$$

of which $\mathrm{q}_{\mathrm{e}}$ and $\mathrm{C}_{\mathrm{e}}$ are ions of metal (in mg/L) sorbed on Tulsion A-62 and present in the solution at equilibrium.

\section{Results and Discussion}

\subsection{The $\mathrm{pH}$ effect}

$\mathrm{A} \mathrm{pH}$ range of 2.0 to 9.0 is used and the effect of $\mathrm{pH}$ on the removal of $\mathrm{Cr}(\mathrm{VI})$ ions by anion exchange resin Tulsion A-62 resin was investigated. Figure 1 indicates that the maximum removal rate for a $213.6 \mathrm{mg} / \mathrm{L}$ aqueous solution containing Chromium (VI) occurred between $\mathrm{pH} 4.0$ and 5.0. Because of chromium precipitation, the $\mathrm{Cr}(\mathrm{VI})$ adsorption decreases when the solution $\mathrm{pH}$ increases beyond 7.0 for the resin. Tulsion resin obtained a positive charge at lower $\mathrm{pH}$ values because of the protonation of quaternary amine groups as well as the predominant chromium species, $\mathrm{HCrO}_{4}^{-}$ion, was adsorbed by electrostatic attraction [12-14].

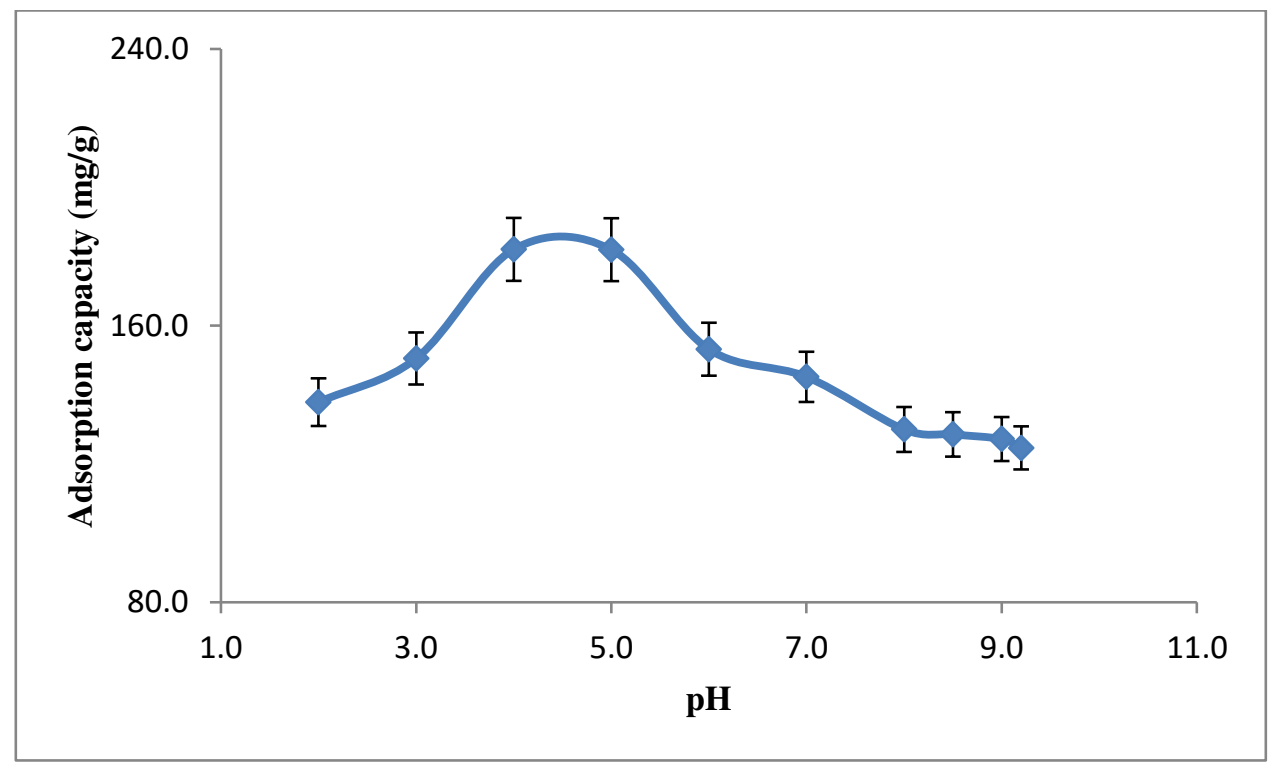

Fig. $1 \mathrm{pH}$ effect on removal of Chromium (VI) 


\subsection{The adsorption time effect}

To have a better understanding of the removal kinetics of $\mathrm{Cr}(\mathrm{VI})$, static-bed experiments were carried out with 0.035 $\mathrm{g}$ of anion exchanger in a fixed volume and concentration of aqueous media. The $\mathrm{Cr}(\mathrm{VI})$ concentration in each sample was spectrophotometrically determined over time. The rate of adsorption of Chromium (VI) increases with time, as shown in figure 2. Within 90 minutes of contact, nearly $94 \%$ of the Chromium (VI) was extracted [15]. The percentage of Chromium (VI) extracted increased rapidly until 300 minutes, when it reached equilibrium. The Chromium (VI) was removed quickly at first due to an excessive amount of plats on the resin surface, but after equilibration was reached due to saturation of the resin plats, the interactivity period had little effect on the elimination of Chromium (VI).

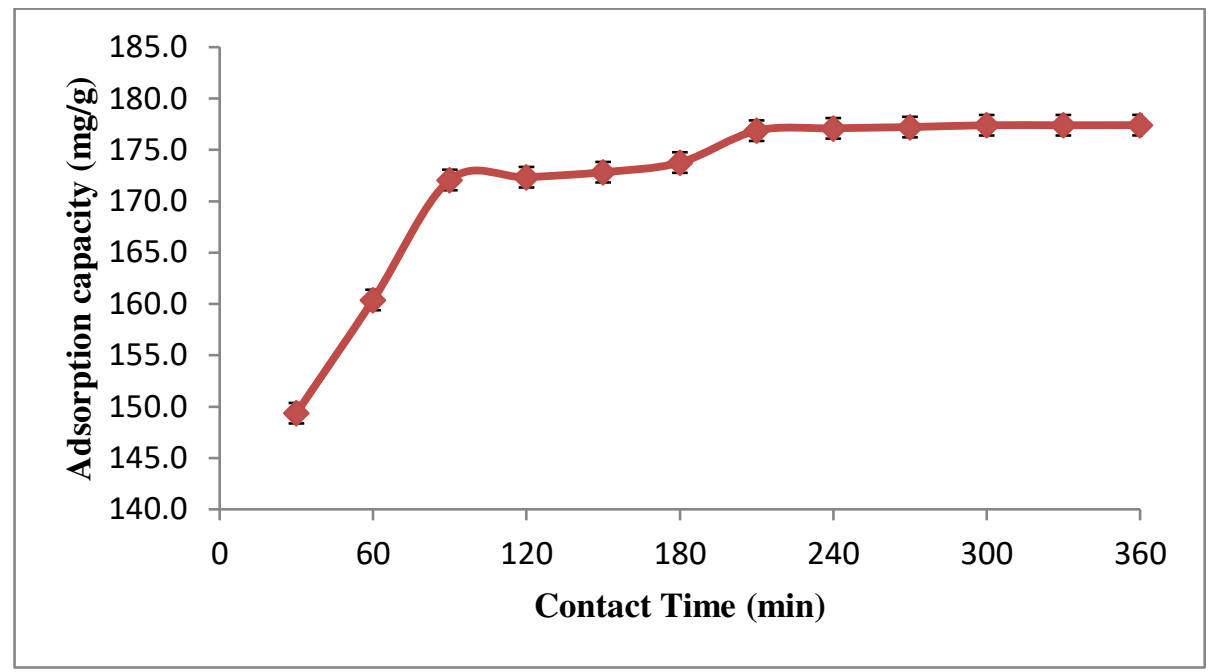

Fig. 2 Adsorption time effect on elimination of Chromium (VI)

\subsection{Effect of resin quantity}

Equilibrium capacity studies on anion exchange resin Tulsion A-62 were carried out by aliquoting aqueous solutions of concentration $213.6 \mathrm{mg} / \mathrm{L}$ and equilibrating for 6 hours at neutral $\mathrm{pH}$ with varying amounts of resin from 0.010 to $0.060 \mathrm{~g}$. Figure 3 shows that the necessary resin dose for maximum $\mathrm{Cr}(\mathrm{VI})$ uptake is $0.035 \mathrm{~g}$, above which the elimination efficiency does not alter significantly [16-17]. The fact that some adsorption sites remain unsaturated during the adsorption process clarifies that raising the adsorbent dosage increases removal efficiency while decreasing adsorption density. Experiments reveal that the amount of $\mathrm{Cr}(\mathrm{VI})$ removed increases as the resin quantity increases because the amount of available sites increases, resulting in a larger surface area [18].

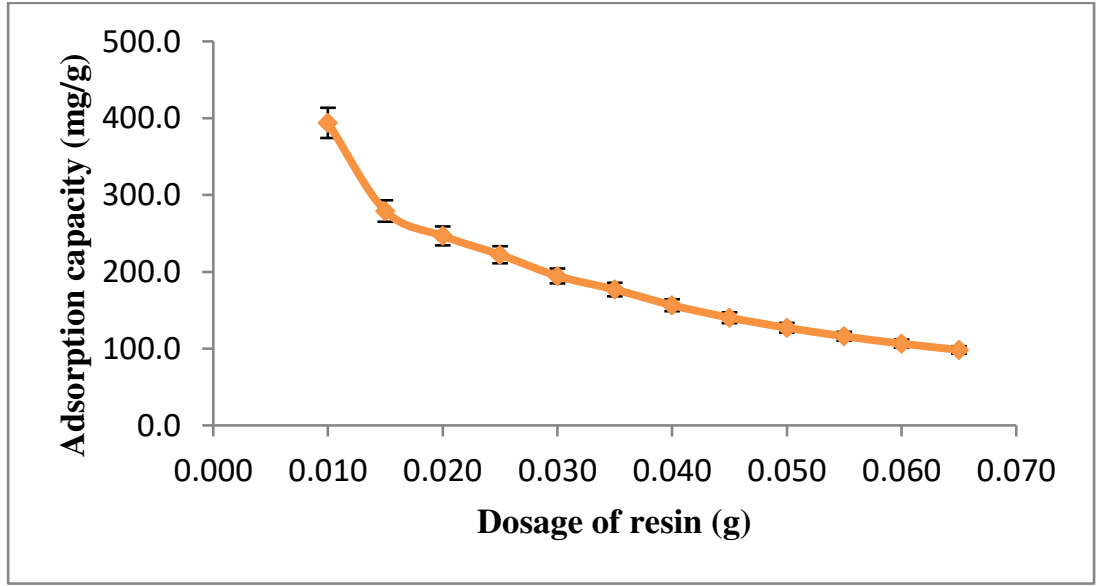

Fig. 3 Influence of quantity of resin on $\mathrm{Cr}(\mathrm{VI})$ removal 


\subsection{Influence of concentration of Chromium (VI)}

The influence of initial concentration on $\mathrm{Cr}(\mathrm{VI})$ removal on Tulsion A-62 (MP) is investigated. The aqueous solution concentration was ranged from 149.5 to $256.3 \mathrm{mg} / \mathrm{L}$. The removal of $\mathrm{Cr}(\mathrm{VI})$ decreases as the initial concentration of the adsorbate in aqueous medium increases at $303 \mathrm{~K}$, as shown in figure 4 . This is because there are a large number of active sites available on the resin for adsorption at first, but as the concentration of $\mathrm{Cr}(\mathrm{VI})$ ions increases, the resin matrix becomes saturated with $\mathrm{Cr}(\mathrm{VI})$ adsorption, reducing $\mathrm{Cr}(\mathrm{VI})$ removal.

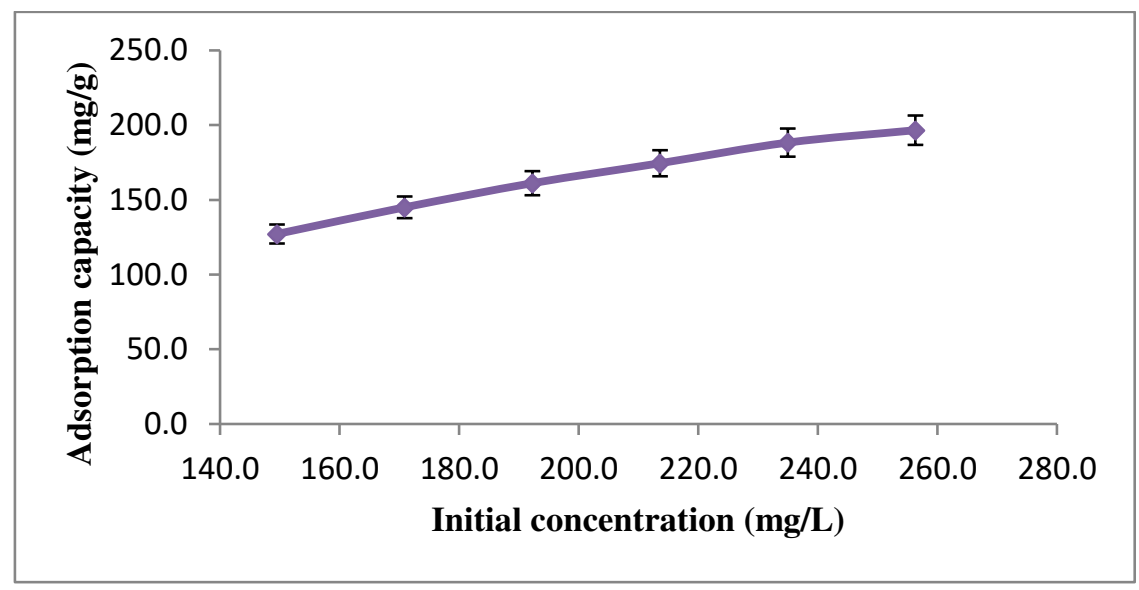

Fig. 4 Influence of $\mathrm{Cr}(\mathrm{VI})$ concentration

\subsection{Characterization of anion exchanger}

Figure 5.a-b displays scanning electron microscopic (SEM) images of Tulsion A-62. The surface of the resin adsorbed with Chromium (VI) was not as smooth as it had been previously. More defects on the resin's surface were found. It was concluded that the sorption of anions that contain Chromium (VI) on the surface of Tulsion A-62 may be the cause. Tulsion A-62 had a lot of chlorine and carbon, which could be from the polymer matrix and exchangeable ion of anion exchange resin, according to the chemical analysis with energy dispersive X-ray (EDX) spectra, as shown in figure 6. Meanwhile, after the adsorption process, elemental chromium (5.04 \% wt) was found in the elemental composition of Tulsion A-62.Figure 7.a-b illustrated the FTIR (Fourier transform infra-red) spectra of Tulsion A-62. The FTIR spectrum of the exchanger (Figure 7a) revealed a wide peak at about $3428 \mathrm{~cm}^{-1}$, that could be because of hydroxyl group's O-H stretching vibration [19]. The peaks around 3015, 2924 and $2856 \mathrm{~cm}^{-1}$ corresponds to stretching of $\mathrm{C}-\mathrm{H}$ of aromatic ring of polystyrene divinyl benzene matrix of anion exchange resin [20]. Further, a significant peak at $1458 \mathrm{~cm}^{-1}$ refers to bending of $\mathrm{CH}_{2}$ of functional group of quaternary ammonium of anion exchanger [21]. In figure 7b, the peak pattern of Tulsion A-62 after adsorption is similar to that of anion exchanger however, an extra peak observed at $940 \mathrm{~cm}^{-1}$ belonging to $\mathrm{Cr}-\mathrm{O}$ stretching vibration, which truly showed the chromium presence on anion exchanger [1].
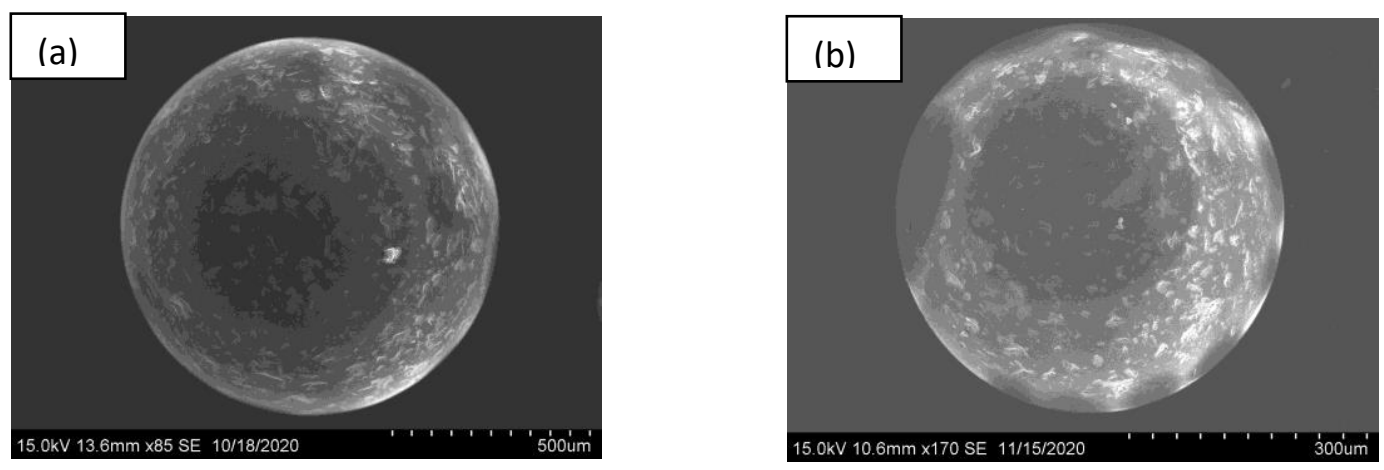

Fig. 5 Micrographs of SEM of Tulsion A-62 (a) before (b) after Chromium (VI) adsorption 


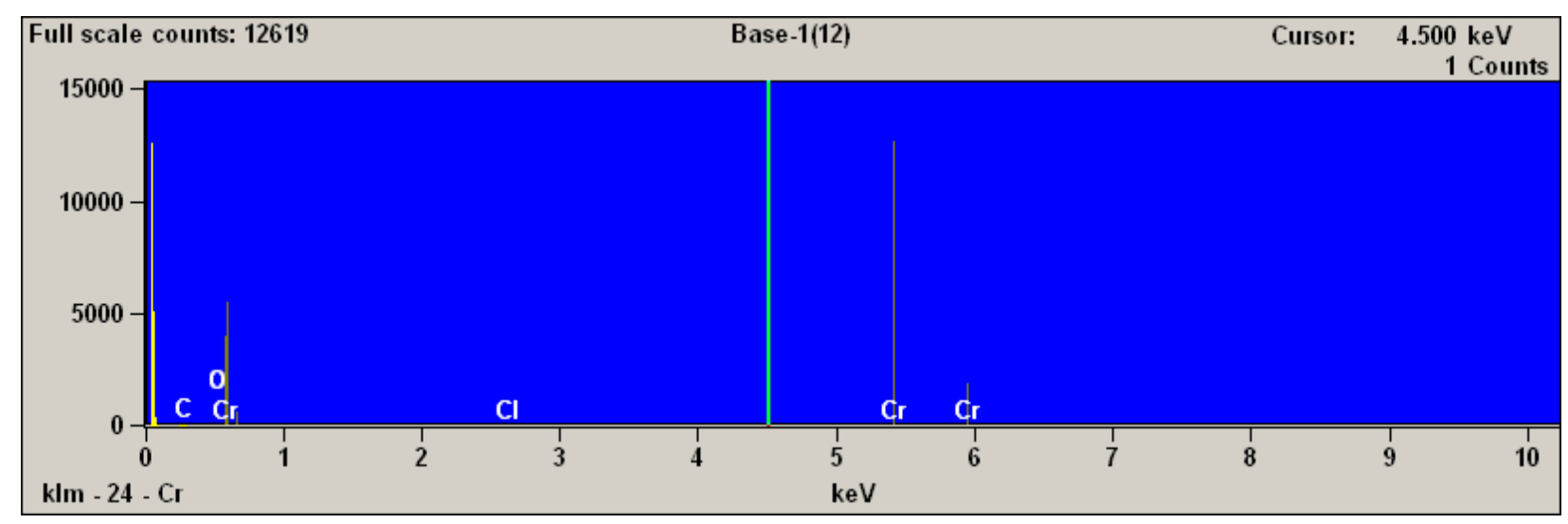

Fig. 6 EDX spectra of Tulsion A-62 after adsorption of Chromium (VI)
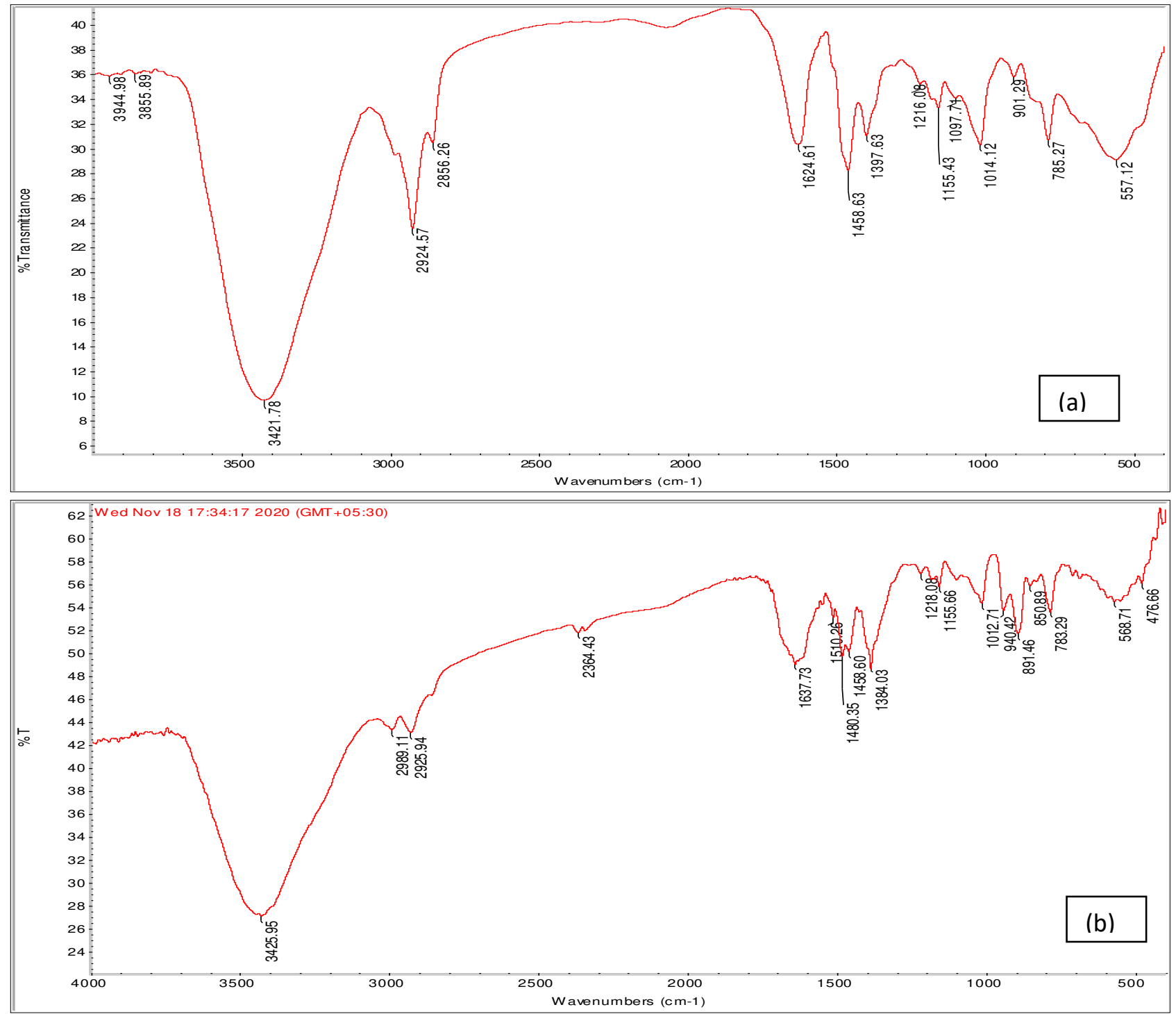

Fig. 7 FTIR spectra of Tulsion A-62 (a) before (b) after adsorption of Chromium (VI) 


\subsection{Analysis of Adsorption isotherm models}

The Sorption process is an important subject for predicting metal partitioning between a solid and a solution. Isotherms of Langmuir and Freundlich are useful for the description of heavy metal adsorption by various adsorbents [22-23]. These isotherms compare the metal uptake per unit weight of the adsorbent, qe, to the equilibrium concentration of the adsorbate in the bulk of the solution, $\mathrm{C}_{\mathrm{e}}$, at constant temperature. The models are defined in broad terms below.

The Langmuir isotherm model is defined as follows:

$$
\frac{\mathrm{C}_{\mathrm{e}}}{\mathrm{q}_{\mathrm{e}}}=\left(\frac{1}{\mathrm{~K}_{\mathrm{L}} \mathrm{q}_{\mathrm{m}}}\right)+\frac{\mathrm{C}_{\mathrm{e}}}{\mathrm{q}_{\mathrm{m}}}
$$

Of which $\mathrm{C}_{\mathrm{e}}$ and $\mathrm{q}_{\mathrm{e}}$ are the beginning and equilibrium metal ion concentrations, $\mathrm{q}_{\mathrm{m}}$ and $\mathrm{K}_{\mathrm{L}}$ are constants denote the capacity and energy of adsorption respectively. Figure 8 represented a linear curve that proved the adsorption on Tulsion A-62 following the Langmuir isotherm. This isotherm suggested that the adsorbent surface has a monolayered homogeneous adsorption with equivalent energy of activation. Table 1 depicts the obtained results.

The Freundlich adsorption isotherm model represents a heterogeneous surface energy system and is represented by the linear equation as (4).

$$
\operatorname{lnq}_{\mathrm{e}}=\ln \mathrm{K}_{\mathrm{F}}+\frac{1}{\mathrm{n}} \ln \mathrm{C}_{\mathrm{e}}
$$

where $\mathrm{q}_{\mathrm{e}}$ denotes capacity of adsorption at equilibrium and $\mathrm{C}_{\mathrm{e}}$ is equilibrium metal ion concentration. The constants, $\mathrm{K}_{\mathrm{F}}$ and $\mathrm{n}$ are acquired by the plot of $\operatorname{lnq}_{\mathrm{e}}$ versus $\ln _{\mathrm{e}}$. As $\mathrm{K}_{\mathrm{F}}$ increases the capacity of adsorption of Tulsion A-62 also increases. The results showed that the equilibrium records were not obeyed the Freundlich model and presented in table 1. On comparing the $\mathrm{R}^{2}$ values of correlation coefficient, it is seen that Langmuir model has better performance than Freundlich model for representing the equilibrium data.

Separation factor $R_{L}$, a non-dimensional parameter of Langmuir isotherm, $\left(R_{L}=1 /\left(1+b C_{o}\right)\right)$, showed that the Chromium (VI) adsorption on Tulsion A-62 was favorable because of $\left(0<R_{L}=0.99<1\right)$ [24].

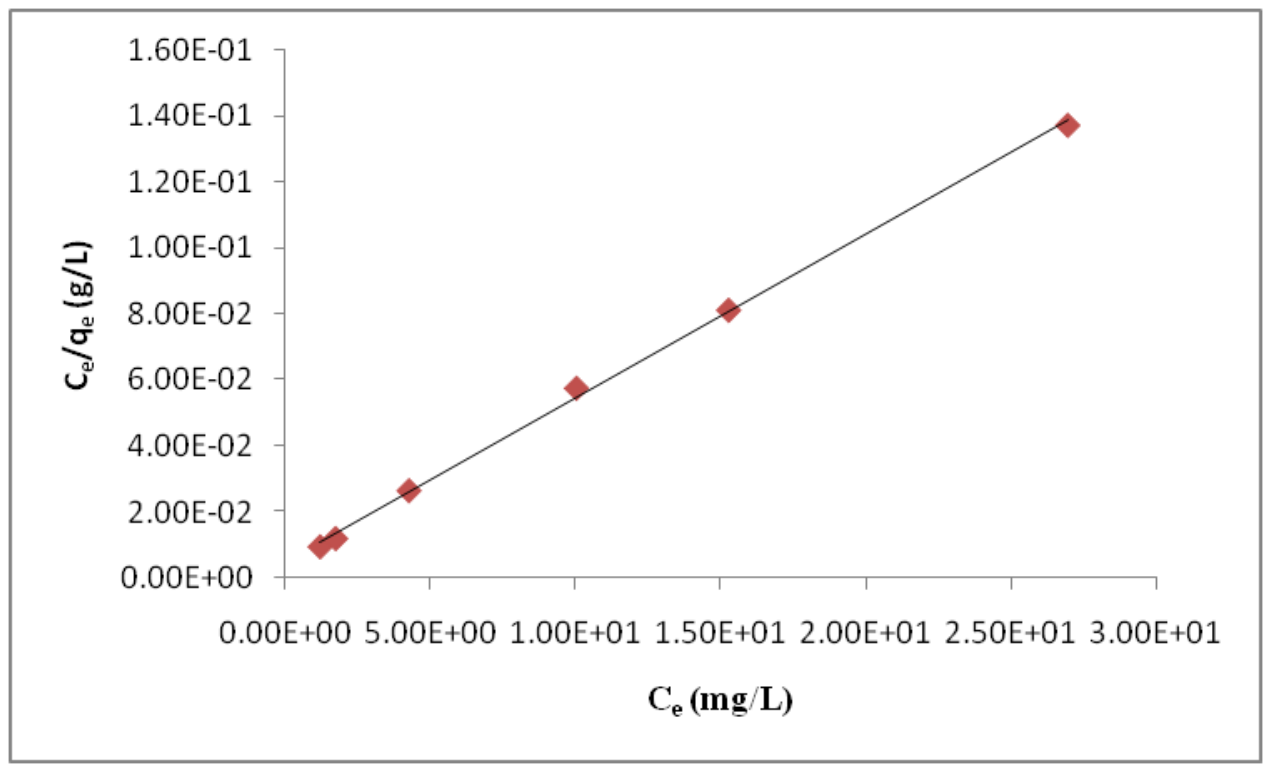

Fig. 8 Linear form of Langmuir isotherm for adsorption of Chromium (VI) on Tulsion A-62 
Table 1. Parameters of adsorption isotherm models

Parameters of Freundlich isotherm Parameters of Langmuir isotherm

\begin{tabular}{ccccccc} 
Anion & \multicolumn{1}{c}{} \\
\cline { 2 - 7 } exchanger & $\mathrm{K}_{\mathrm{F}}$ & $\mathrm{n}$ & $\mathrm{R}^{2}$ & $\mathrm{q}_{\mathrm{m}}{ }^{\mathrm{a}}$ & $\mathrm{K}_{\mathrm{L}}$ & $\mathrm{R}^{2}$ \\
\hline Tulsion A-62 & 4.35 & 7.6 & 0.96 & 201.6 & 1.04 & 0.99 \\
\hline${ }^{\mathrm{a} \mathrm{mg} / \mathrm{g} \text { resin }}$ & & & & &
\end{tabular}

\subsection{Adsorption Kinetics}

Reversible first-order kinetics describes the rate of sorption of Chromium (VI) on Tulsion A-62. It also suggests the necessary residence time of sorption of metal ions on Tulsion A-62. From figure 9, the forward $\left(\mathrm{k}_{\mathrm{f}}\right)$, backward $\left(\mathrm{k}_{\mathrm{b}}\right)$ and the reaction rate coefficient $(\mathrm{k})$ were evaluated [25-26] for Chromium (VI) adsorption from aqueous solution having the concentration $213.6 \mathrm{mg} / \mathrm{L}$. The data $\mathrm{k}_{\mathrm{f}}\left(1.472 \times 10^{-2}\right)>\mathrm{k}_{\mathrm{b}}\left(4.27 \times 10^{-4}\right)$ indicated the dominance of adsorption.

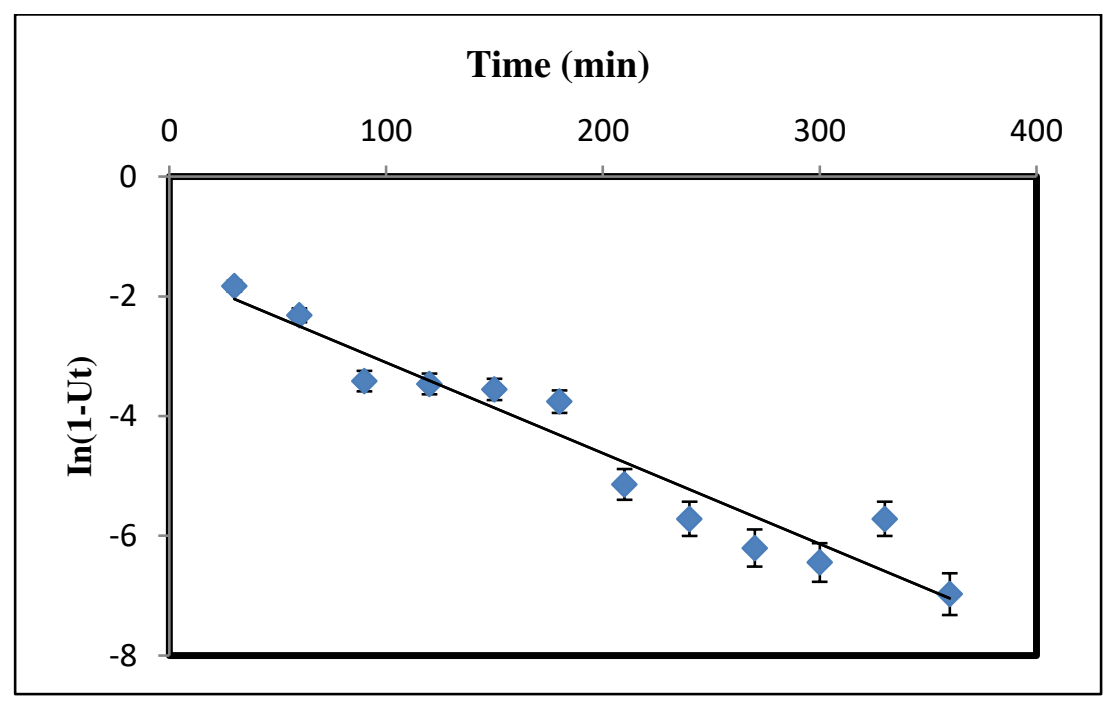

Fig. 9 Kinetics of adsorption of Chromium (VI) on Tulsion A-62

\subsection{Thermodynamic parameters}

The influence of temperature on Chromium (VI) adsorption by Tulsion A-62(MP) was used to determine parameters related to thermodynamic, like Gibbs free energy change $\left(\Delta \mathrm{G}^{\circ}\right)$, change in enthalpy $\left(\Delta \mathrm{H}^{\circ}\right)$ and change in entropy $\left(\Delta \mathrm{S}^{\circ}\right)$, as per the below equations[27,28]:

$$
\begin{aligned}
& \operatorname{In} K d=\frac{\Delta S^{\circ}}{R}-\frac{\Delta H^{\circ}}{R T} \\
& \Delta G^{\circ}=\Delta H^{\circ}-T \Delta S^{\circ}
\end{aligned}
$$




$$
K d=\frac{C s}{C e}
$$

Of which $K_{\mathrm{d}}$ is the sorption equilibrium constant, $C_{\mathrm{e}}$ is the concentration at equilibrium of $\mathrm{Cr}(\mathrm{VI})(\mathrm{mg} / \mathrm{L})$ in aqueous solution, $C_{\mathrm{s}}$ is the concentration of $\mathrm{Cr}(\mathrm{VI})$ at equilibrium $(\mathrm{mg} / \mathrm{L})$ adsorbed on the surface of resin, $R$ is the ideal gas constant $(8.314 \mathrm{~J} / \mathrm{mol} \mathrm{K})$ and $T$ is the kelvin temperature. The slope and intercept of plots $\ln \mathrm{K}_{\mathrm{d}} \mathrm{vs}$. 1/T is used to measure the values of enthalpy and entropy changes. Table 2 displays the $\mathrm{R}^{2}$ value of 0.992 for Tulsion A-62(MP). The sorption's spontaneous nature is suggested by negative $\mathrm{G}^{0}$ values. The optimistic indicator $\mathrm{H}^{0}$ revealed that the endothermic nature of sorption process, with higher temperatures being more favorable. The positive value of $S^{0}$, showing that during the adsorption process, there is more randomness at the solid/liquid interface.

Table 2. Thermodynamic parameters for the sorption of $\mathrm{Cr}(\mathrm{VI})$ by anion exchange resin

\begin{tabular}{cccccc}
\hline Resin & $\mathrm{T} / \mathrm{K}$ & $\log \mathrm{K}_{\mathrm{d}}$ & $\mathrm{G} / \mathrm{kJ} \mathrm{mol}^{-1}$ & $\mathrm{H} / \mathrm{kJ} \mathrm{mol}^{-1}$ & $\mathrm{~S} / \mathrm{kJ} \mathrm{mol}^{-1} \mathrm{~K}^{-1}$ \\
\hline \multirow{3}{*}{ Tulsion A-62(MP) } & 303 & 0.7254 & -1.83 & & \\
& 313 & 0.7953 & -2.07 & 3.71 & 0.018 \\
& 323 & 0.8161 & -2.19 & & \\
\hline
\end{tabular}

\section{Conclusions}

Ion exchange resins, according to the literature, are capable polymeric substances used for the purification of polluted water with chosen thrash. So the resin efficiency was presented here. Tulsion A-62 is most efficient at extracting Chromium (VI) when the $\mathrm{pH}$ is between 4.0 and 5.0. Adsorption kinetics are influenced by resin dosage and chromium concentration. Equilibrium data obeyed the Langmuir isotherms. The non-dimensional separation factor $\left(\mathrm{R}_{\mathrm{L}}\right)$ is a strong predictor of Chromium (VI) adsorption. Tulsion A-62 is a capable material for the eliminating Chromium (VI) from water and waste water.

\section{Data Availability}

The datasets generated during and/or analysed during the current study are available from the corresponding author on reasonable request.

\section{Compliance with ethical standards}

Conflict of interest: The authors declare no conflict of interest.

\section{Funding}

Not applicable.

\section{Author's Contributions}

All authors contributed to the study conception and design. Material preparation, data collection and analysis were performed by Harish N. Revankar, Prasanna S. Koujalagi, Vijayendra R. Gurjar and Raviraj M. Kulkarni. The first draft of the manuscript was written by Harish Revankar and all authors commented on previous versions of the manuscript. All authors read and approved the final manuscript.

\section{Acknowledgments}

The ion exchanger used in this study was provided by Thermax Limited, Pune, India, which the authors gratefully acknowledge.

\section{References}

1. S.Edebali, E.Pehlivan, Evaluation of IRS96 and Dowex $1 \mathrm{X} 8$ ion exchange resins for the removal of $\mathrm{Cr}(\mathrm{VI})$ from aqueous solution. Chem. Eng. J. 16,161-166 (2010) 
2. P.S.Koujalagi, S.V.Divekar, R.M.Kulkarni, R.K.Nagarale, Kinetics, thermodynamic and adsorption studies on removal of chromium (VI) using Tulsion A-27(MP) resin. Desalin. Water Treat. 51, 3273-3283 (2013)

3. S.S Salih, T.K.Ghosh, Preparation and characterization of bioadsorbent beads for chromium and zinc ions adsorption. Cogent Environ. Sci. 3,1401577 (2017)

4. Fanglian Fu, Wang Qi, Removal of heavy metal ions from wastewaters: A review. J. Environ. Manag. 92, 407418 (2011)

5. Barnhart J, Regul. Toxicol.Pharmacol. 26(1), 53-57 (1997)

6. Xiofan Li, Shaoyuan Shi, Hongbin Cao,Yuping Li,Dongyao Xu, Comparative Study of Chromium(VI) Removal from Simulated Industrial Wastewater with Ion Exchange Resins. Rus. J. Phys. Chem. A. 92(6),1229-1236 (2018)

7. B. Natarajan, S. Nangarajan, Utilization of agricultural weed for the removal of $\mathrm{Cr}(\mathrm{VI})$ from aqueous solution. Acta Chim. Slov. 57(3), 693-699 (2010)

8. N. Ben Issa, A. Elmaghrabie, Y. Elhebshi, A. Hamid, Removal of Chromium (VI) From Aqueous Solution By Sorption on To Selective Silver Resin. J. Appl. Chem. 12(5), 08-12 (2019)

9. K. Mulani, V. Patil, N. Chavan, K. Donde, Adsorptive removal of chromium(VI) using spherical resorcinolformaldehyde beads prepared by inverse suspension polymerization. J. Polym. Res. 26, 41 (2019)

10. J. Lakatos, S.D. Brown, C.E. Snape, Coals as sorbents for the removal and reduction of $\mathrm{Cr}(\mathrm{VI})$ from aqueous waste streams. Fuels 81(5), 691-698 (2002)

11. P.S. Koujalagi, H.N. Revanakar, R.M. Kulkarni, Studies on Hexavalent Chromium Removal from Electroplating Rinse Solution onto an Anion Exchanger. AIP Conf. Proc. 2274(1), 040003(1-8) (2020)

12. E.A Ayuso, A. Sanchez, X. Gand Querol, Purification of metal electroplating waste waters using zeolites. Water Res. 37, 4855-4862 (2003)

13. P.S. Koujalagi, S.V. Divekar, R.M. Kulkarni, Adsorption studies of hexavalent chromium on weak base macroporous anion exchanger Tulsion A $2 \mathrm{X}(\mathrm{MP})$ in water and organic solvent mixed media. Asian J. Chem. 30(5),1083-1087 (2018)

14. M.A. Hanif, R. Nadeem, H.N. Bhatti, N.R. Ahmad, T.M. Ansari, Ni(II) biosorption by Cassia fistula (Golden Shower) biomass. J. Hazard. Mater. 139(2), 345-355 (2007)

15. S. Rengaraj, K.H. Yeon, S.Y. Kang, J.U. Lee, K.W. Kim S.H. Moon, Studies on adsorptive removal of Co(II), $\mathrm{Cr}(\mathrm{III})$ and Ni(II) by IRN77 cation-exchange resin. J. Hazard. Mater. B92, 185-198 (2002)

16. Rengaraj S, Moon S H. (2002) Kinetics of adsorption of Co(II) removal from water and wastewater by ion exchange resins. Water Res. 36(7), 1783-1793.(2002)

17. J. Al Abdullah, A. Al Lafi, T. Alnama, W. Al Masri, M. Amin Yand Alkfri, Adsorption Mechanism of Lead on Wood/Nano-Manganese Oxide Composite. Iran. J. Chem. Chem. Eng. 37(4), 131-144 (2018)

18. D. Kauspediene, E. Kazlauskiene, R. Cesuniene, A. Gefeniene, R. Ragauskas, A. Selskiene, Removal of the phatalocynaine dye from acidic solutions using resin with the polystyrene divinylbenzne matrix. Chemija 24(3), 171-181 (2013)

19. S. Ghosh, K.J. Dhole, M.K. Tripathy, R. Kumar, R.S. Sharma, FTIR spectroscopy in the characterization of the mixture of nuclear grade cation and anion exchange resins. J. Radioanal. Nucl. Chem. 304(2), 917-923 (2015)

20. S.M. Alshehri, M. Naushad, T. Ahamad, Z.A. Alothman, A. Aldalbahi, Synthesis, characterization of curcumin based ecofriendly antimicrobial bio-adsorbent for the removal of phenol from aqueous medium. Chem. Eng. J. 254, 181-189 (2014)

21. K. Bedoui, I. Bekri-Abbes, E. Srasra, Removal of cadmium(II) from aqueous solution using pure smectite and Lewatite S 100: the effect of time and metal concentration. Desalination 223, 269-273 (2008)

22. Yu Q, P. Kaewsarn, Binary adsorption of copper (II) and cadmium (II) from aqueous by biomass of marine alga Durvillaea potatorum. Sep. Sci. Technol. 34(8), 1595-1606(1999)

23. B. Haerizade, M. Ghavami, M. Koohi, S. Janitabar Darzi, N. Rezaee, M. Kasaei, Green Removal of Toxic Pb(II) from Water by a Novel and Recyclable Ag/ $\gamma$-Fe2O3@r-GO Nanocomposite. Iran. J. Chem. Chem. Eng. 37(1), 29-37 (2018)

24. D. Haddad, A. Mellah, D. Nibou, S. Khemaissia, Promising enhancement in the removal of uranium ions by surface-modified activated carbons: kinetic and equilibrium studies. J. Environ. Eng. 144 (5), 04018027 (2018)

25. F. Gode, E.A Pehlivan, A comparative study of two chelating ion-exchange resins for the removal of chromium (III) from aqueous solution. J. Hazard. Mater. B100, 231-243 (2003)

26. Cheng Ting, Chen Chen, Tang Rong, Han Cheng-Hui, Tian Yuan, Competitive Adsorption of $\mathrm{Cu}, \mathrm{Ni}, \mathrm{Pb}$ and $\mathrm{Cd}$ from Aqueous Solution onto Fly Ash-Based Linde F(K) Zeolite. Iran. J. Chem. Chem. Eng. 37(1), 61-72 (2018)

27. T. Shi, Z.Wang, Y. Liu, S. Jia, D. Changming, Removal of hexavalent chromium from aqueous solutions by D301, D314 and D354 anion-exchange resins. J. Hazard. Mater. 161(2-3), 900-906 (2009)

28. B. Singha, S.K Das, Biosorption of $\mathrm{Cr}(\mathrm{VI})$ ions from aqueous solutions: kinetics, equilibrium, thermodynamics and desorption studies. Colloids Surf. B: Biointerfaces 84(1), 221-232 (2011) 
Figures

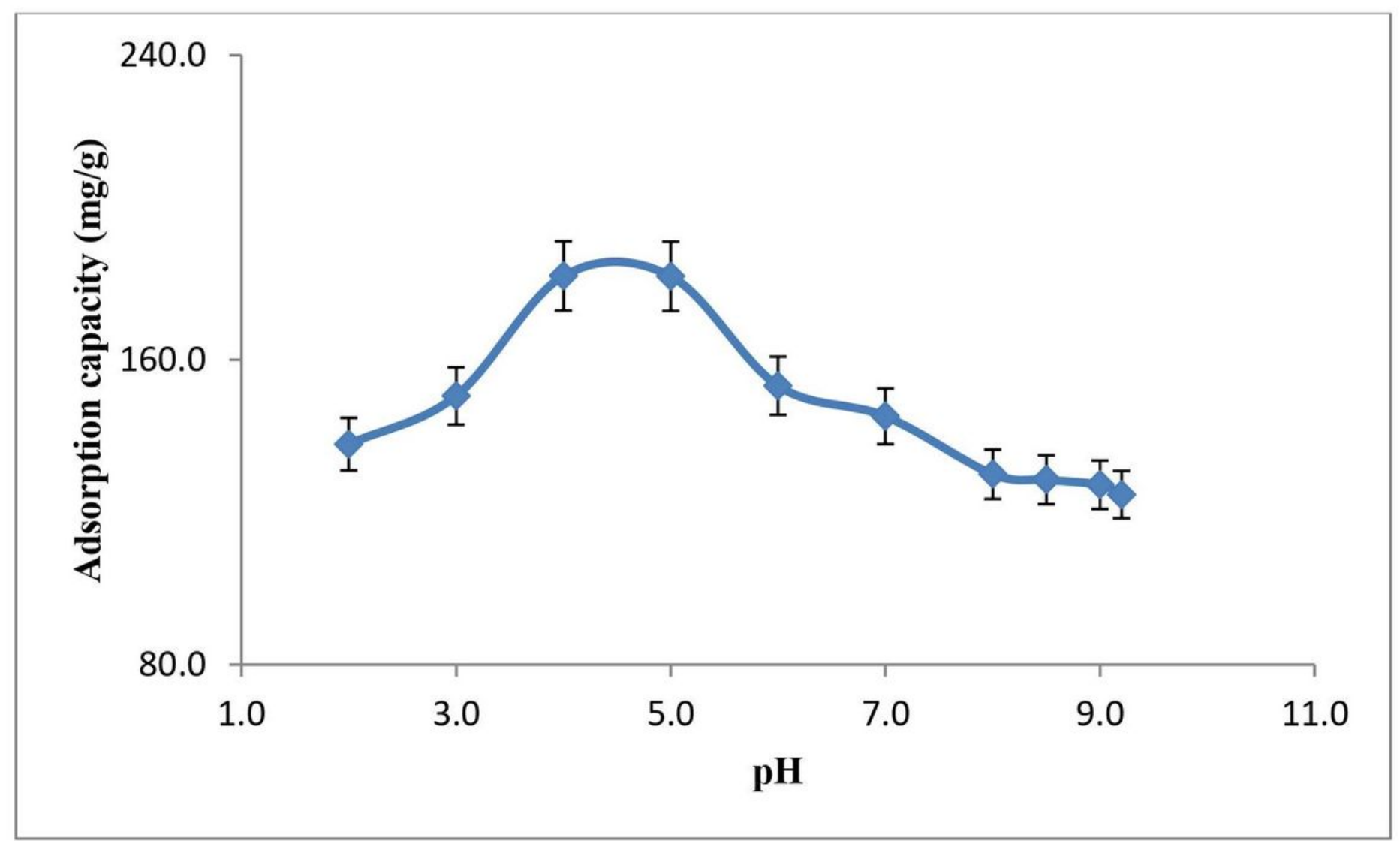

Figure 1

pH effect on removal of Chromium (VI) 


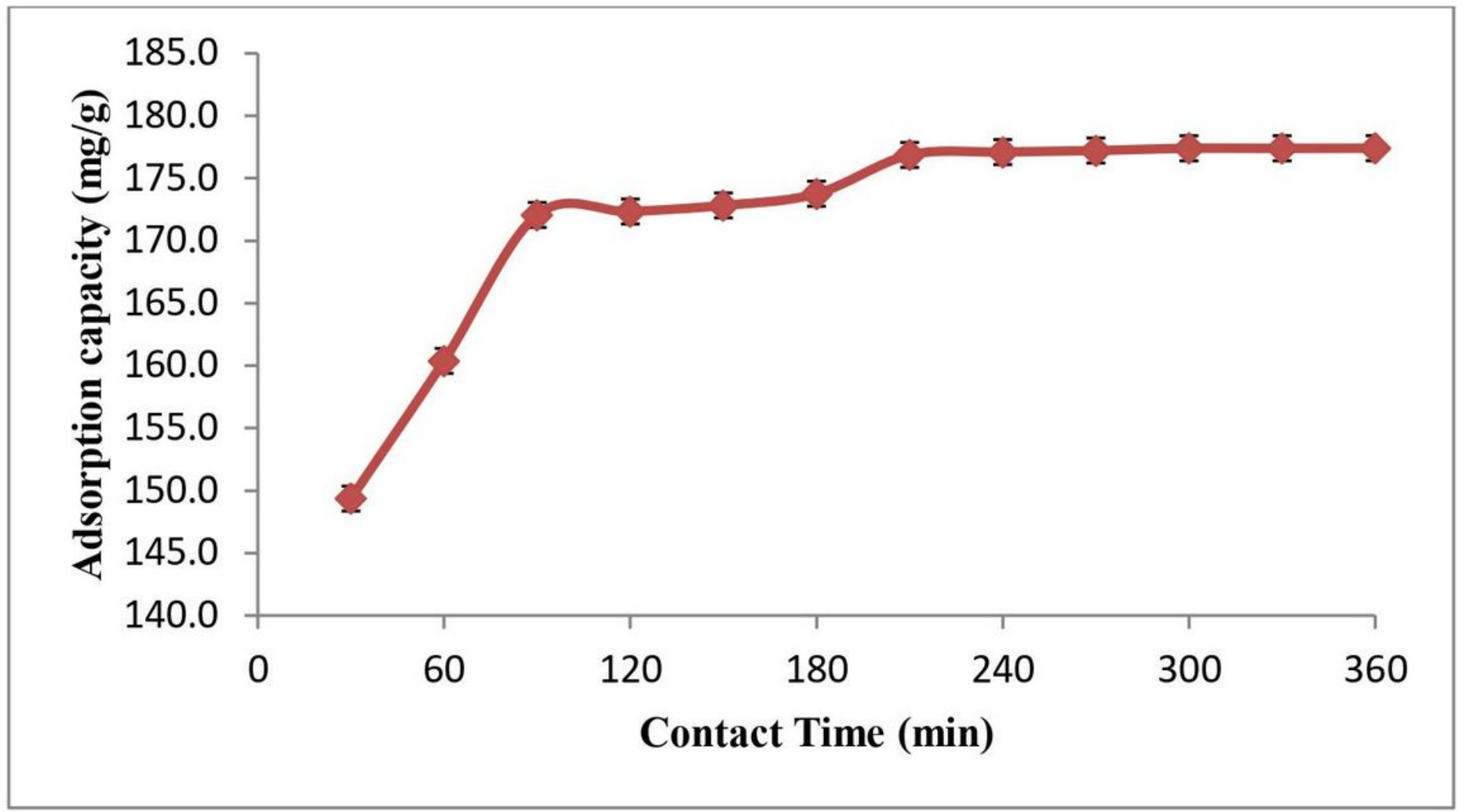

Figure 2

Adsorption time effect on elimination of Chromium (VI)

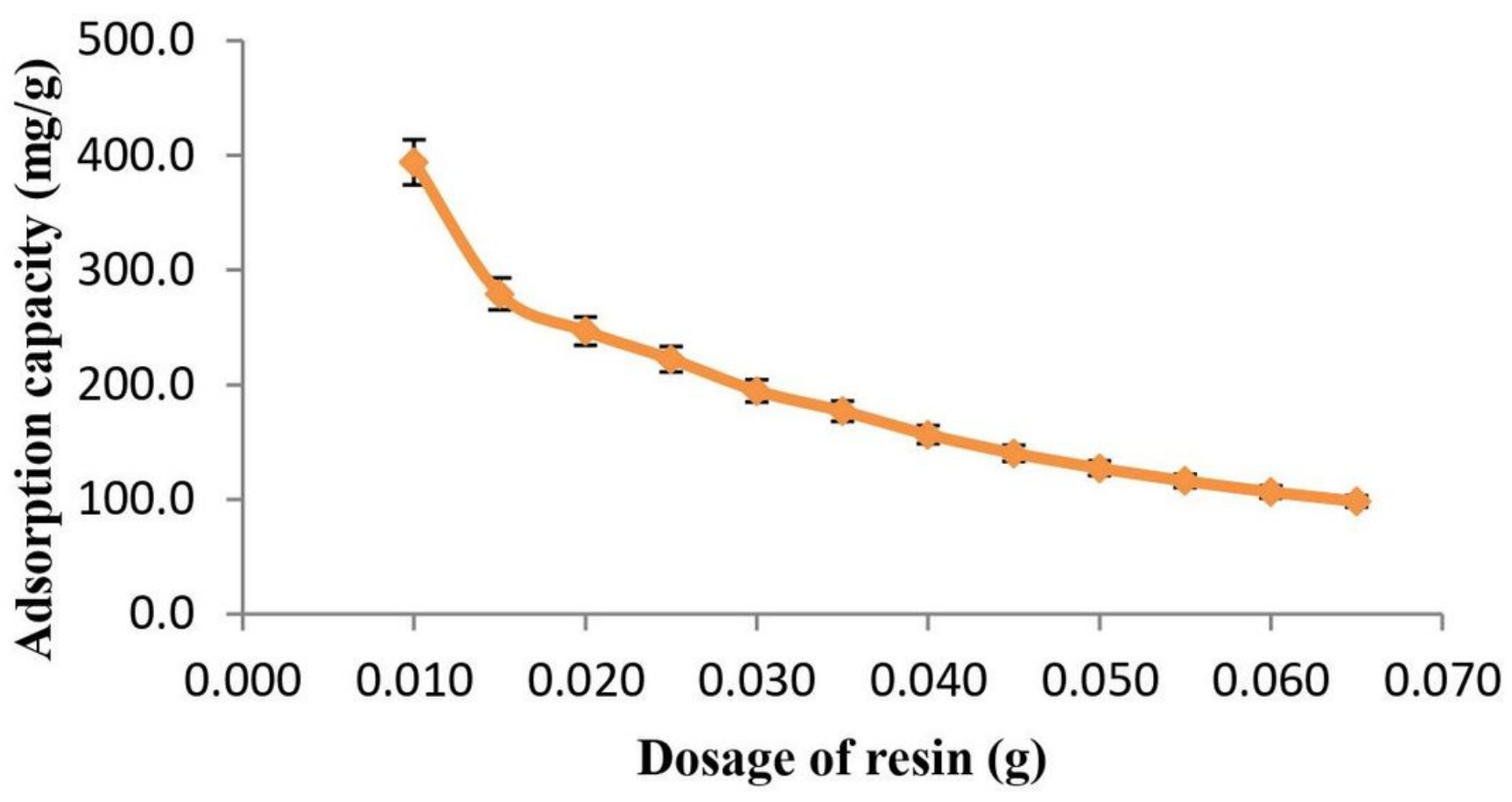


Figure 3

Influence of quantity of resin on $\mathrm{Cr}(\mathrm{VI})$ removal

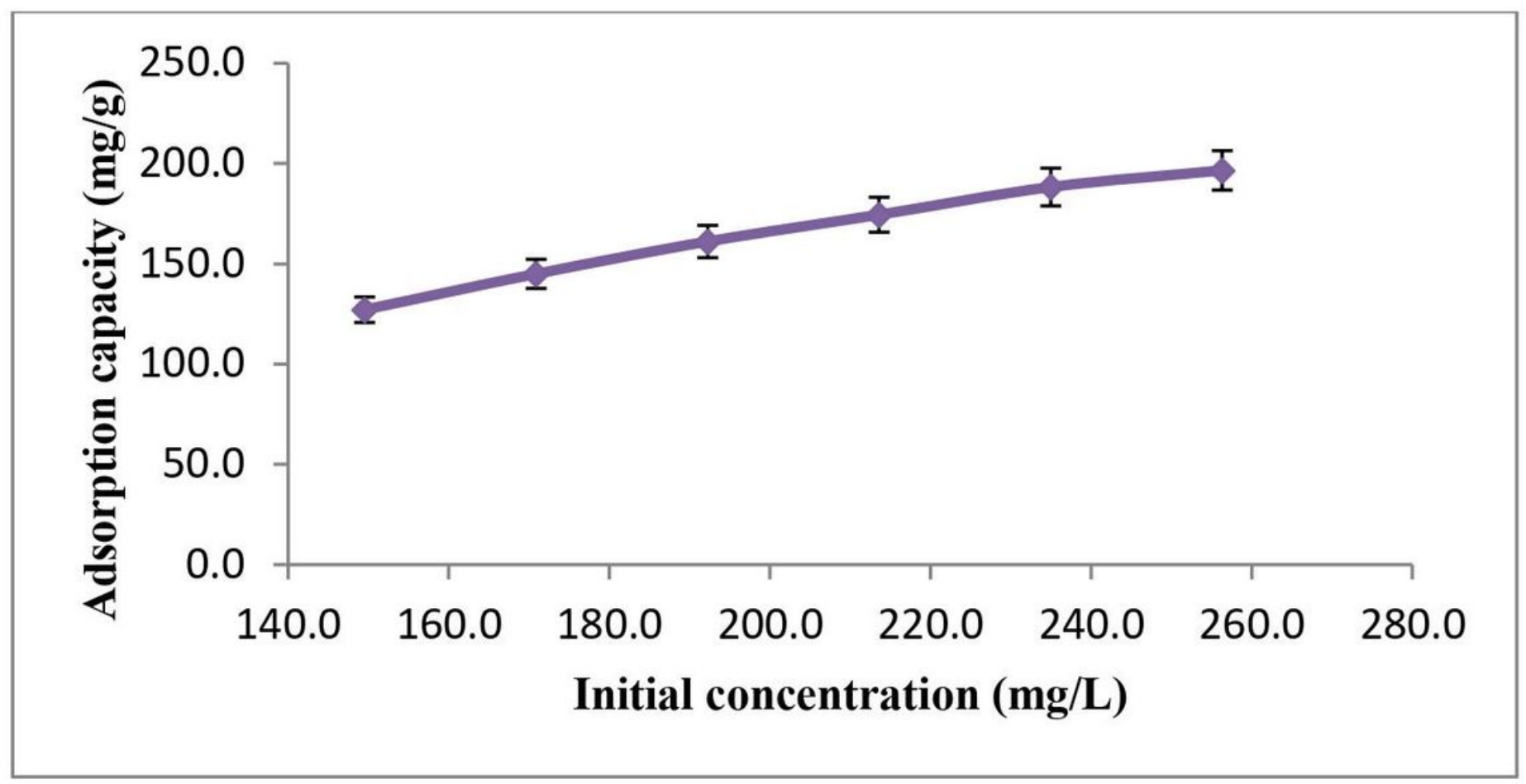

Figure 4

Influence of $\mathrm{Cr}(\mathrm{VI})$ concentration
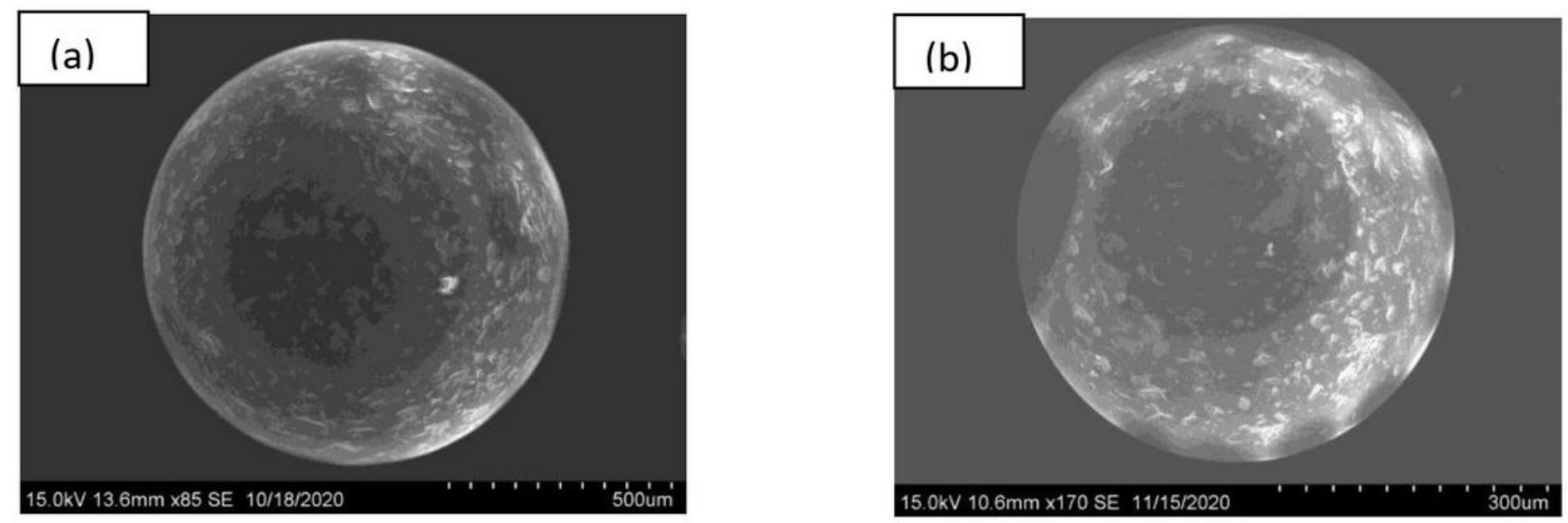

Figure 5

Micrographs of SEM of Tulsion A-62 (a) before (b) after Chromium (VI) adsorption 


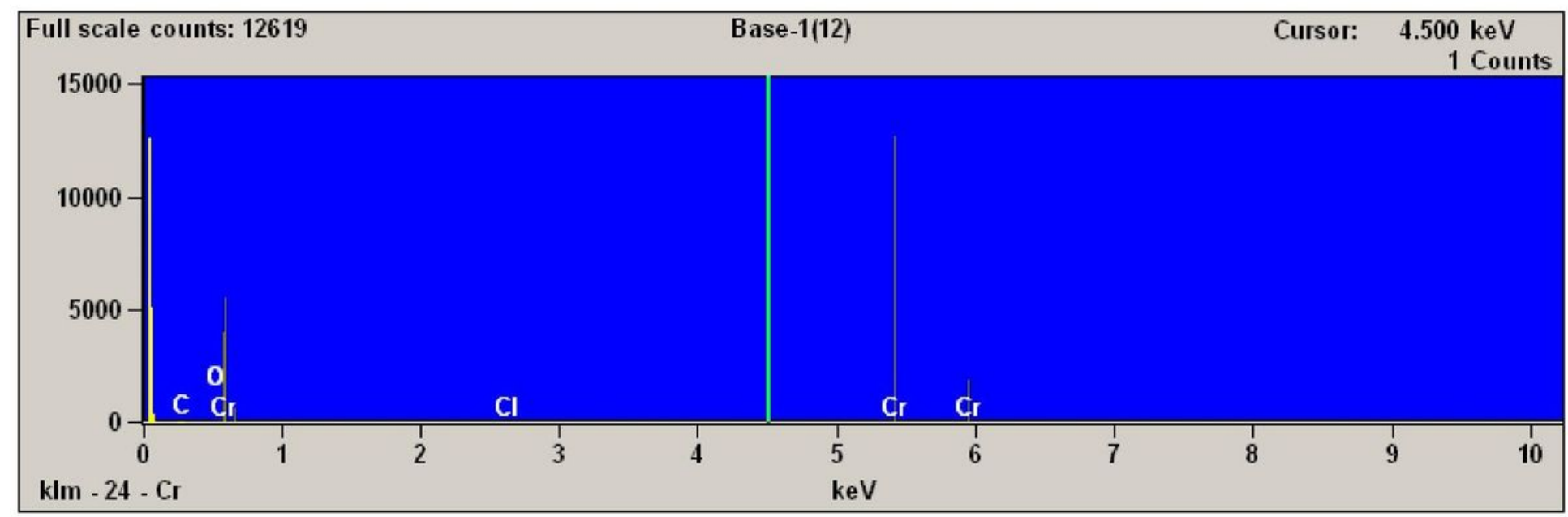

Figure 6

EDX spectra of Tulsion A-62 after adsorption of Chromium (VI) 

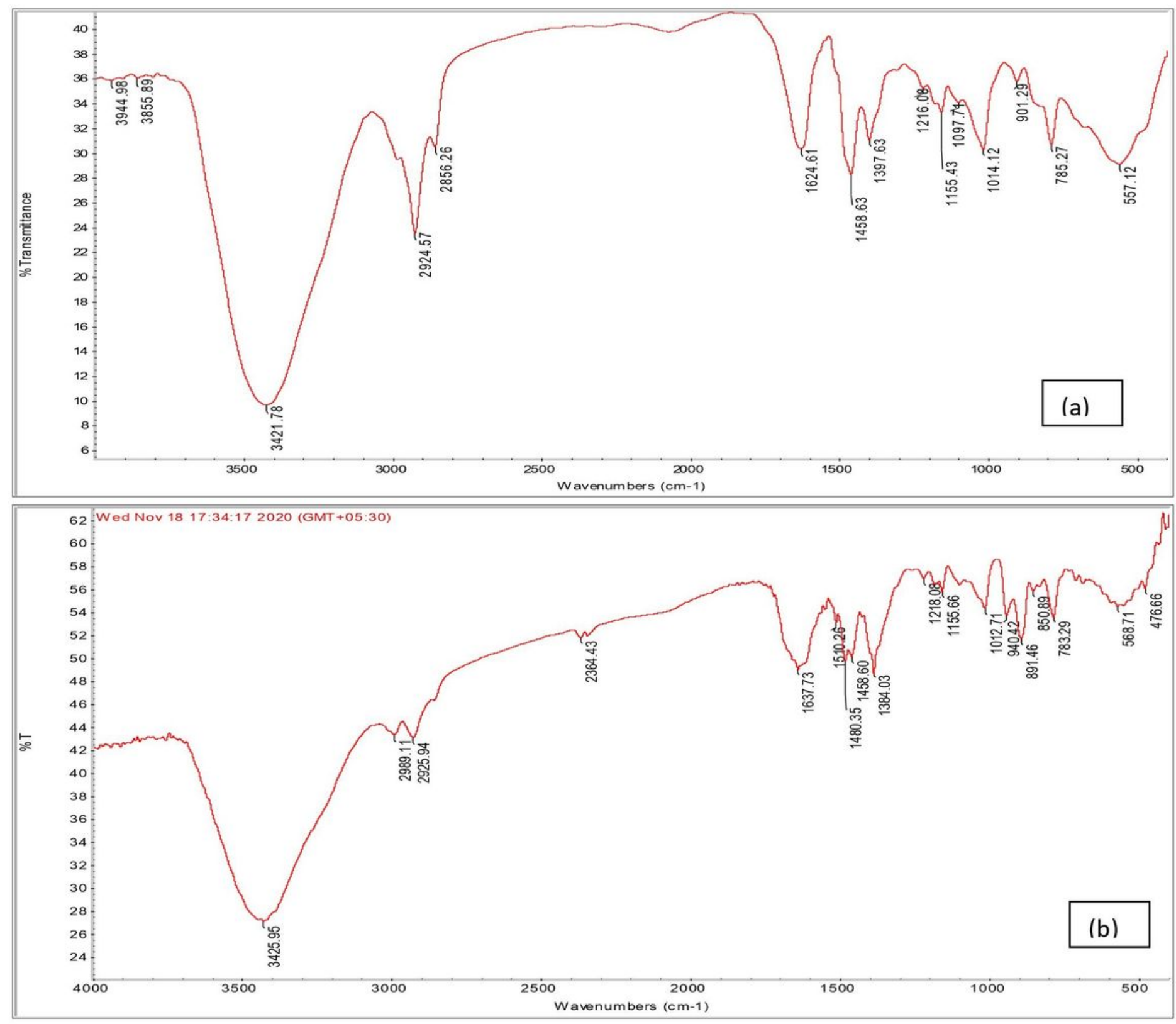

Figure 7

FTIR spectra of Tulsion A-62 (a) before (b) after adsorption of Chromium (VI) 


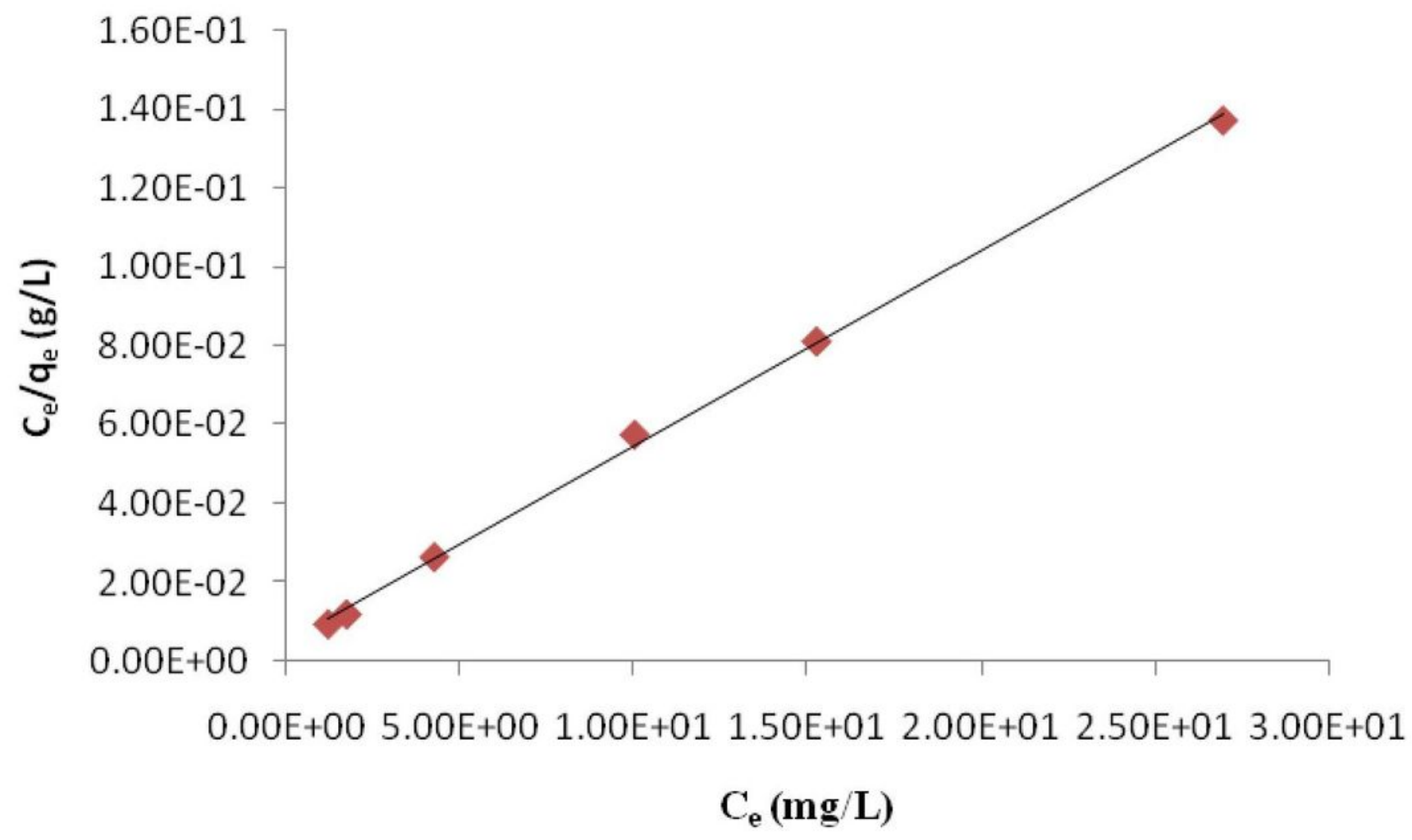

Figure 8

Linear form of Langmuir isotherm for adsorption of Chromium (VI) on Tulsion A-62 


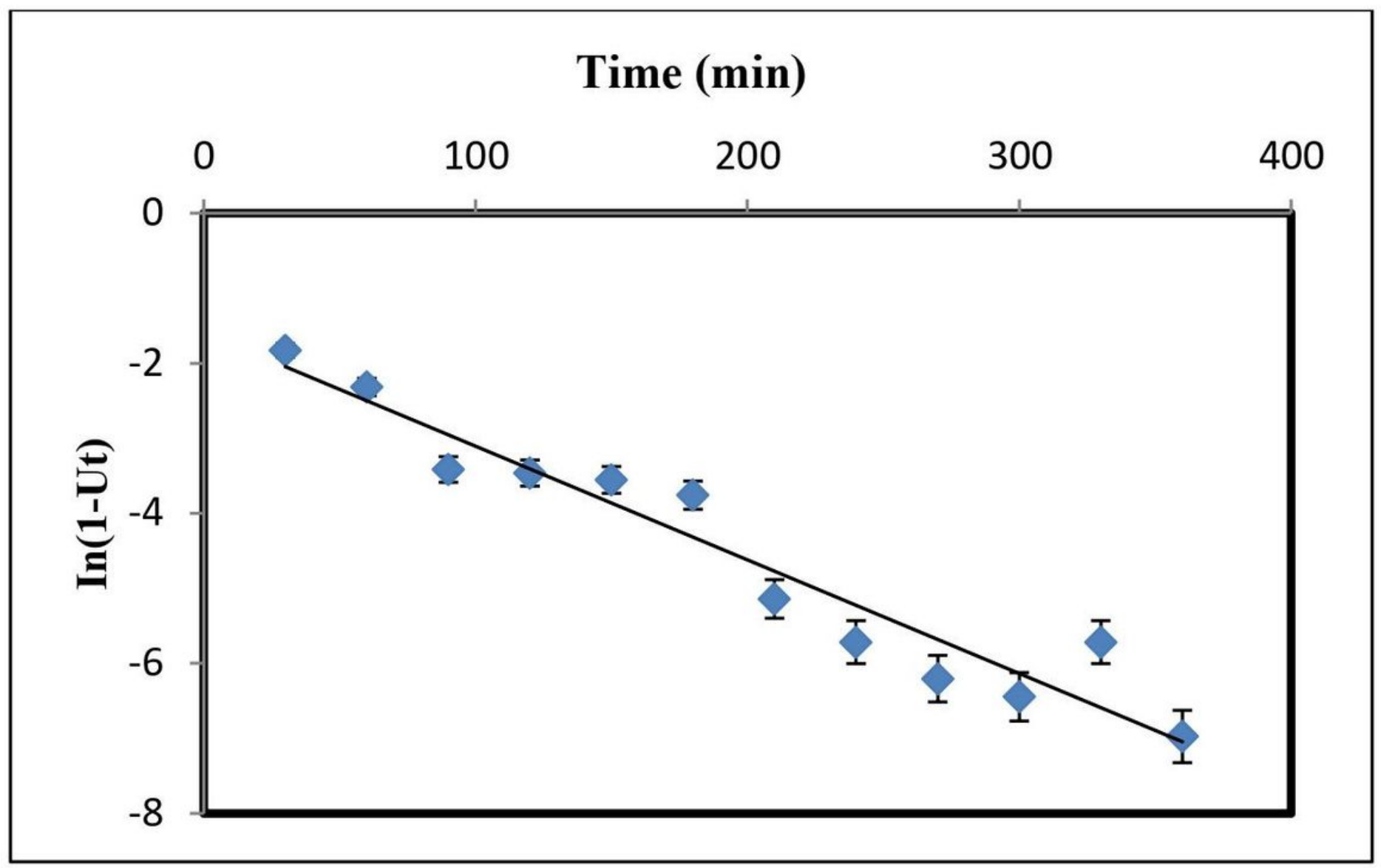

Figure 9

Kinetics of adsorption of Chromium (VI) on Tulsion A-62 